\title{
PROFESINĖS VOKIEČIŲ KALBOS MOKYMAS
}

\author{
Irena Miculevičienè
}

Vilniaus Gedimino technikos universitetas, Saulètekio al. 11, LT-10223 Vilnius

El. paštasvvka@vv.vtu.lt

Šiame straipsnyje nagrinejjamas vokiečiu kalbos mokymas tam tikrų specialybiu besimokančiu studentu grupesse. Profesinés užsienio kalbos mokoma jaunuomenè, dar neturinti jokios praktinés patirties. Todèl dirbant su specialiu žodynu svarbiausia yra supažindinti besimokančiuosius su mokymo tikslais, technika ir metodais, kurie jiems padeda savarankiškai suprasti, išmokti žodžius. Čia kalbama ir apie darba su tekstais, ju parinkima, nuolat besikartojančias juose tam tikras gramatines struktüras, kurias labai svarbu atpažinti ir išsifruoti, o atgaminant - supaprastinti.

Reikšminiai žodžiai: bendrinė šnekamoji kalba, profesinė vokiečių kalba, dalykinis žodynas, dalykinių tekstų ypatumai, gramatinès struktūros.

\section{Ivadas}

Ką reiškia mokytis su profesija susijusios vokiečių kalbos, kitaip tariant, profesinès vokiečių kalbos? Išgirdus šią sąvoką, pirmiausia prieš akis iškyla ịvairūs terminai, negirdètas žodynas bei sudètingi ir sunkiai suvokiami ịvairių specialybių tekstai. Tačiau čia bus kalbama ne apie mokomojo dalyko (tam tikros disciplinos) dèstymą vokiškai, bet išdèstytos kai kurios mintys apie dalykinès vokiečių kalbos mokymosi ypatumus tam tikras specialybes studijuojančių studentų grupėse. Kai kurios mintys kilusios ir išgirstos besitobulinant Berlyno Gètès institute organizuotame seminare Deutsch im Beruf, analizuojant tam tikrą literatūrą bei remiantis praktine patirtimi.

\section{Problemos aktualumas}

Didžiumai Vilniaus Gedimino technikos universiteto studentų vokiečių kalba yra privaloma disciplina. Vokiečių kalbos, kaip užsienio kalbos, mokymas ịtrauktas ị daugelio aukštesniųju mokyklų, kolegijų, aukštųjų mokyklų mokymo planus. Taigi profesinès vokiečių kalbos mokymas yra skirtas jaunuomenei, kuri dar neturi jokios praktinès patirties. Daugumos su pasirinkta specialybe susijusių dalykų mūsų universitete studentai pradeda mokytis tik antraisiais studijų metais, o užsienio kalba daugeliui specialybių studentų dèstoma tik du pirmuosius semestrus pirmaisiais studijų metais. Kad ir kaip būtų keista, su savo specialybe jie susipažizsta pirmiausia per užsienio kalbos paskaitas, nagrinėdami profesinius tekstus vokiečių kalba. Taigi mokant užsienio kalbos techninių specialybių studentus būtina turèti tai omenyje. Tik ar tikslinga mokyti studentus specialybės dalykų užsienio kalba, jei jie dar nesusipažinę su savo specialybe praktiškai? Kai studentai aukštesniuose kursuose pradeda mokytis specialiųjų dalykų, užsienio kalbą dèstyti baigiama. Lieka tik viltis, kad studentai, baigę studijas, atsivers vokiečių kalbos užrašus ir prireikus bandys prisiminti kažkada pirmame kurse girdètus terminus bei kalbines struktūras. 


\section{Tiriamojo darbo analizè ir mokomojo darbo rekomendacijos}

Anot Hermanno Funko, su profesija susietame vokiečių kalbos mokyme pastebimos trys pagrindinès koncepcijos: a. Paskaitų metu dèstoma bendrinè šnekamoji kalba, retkarčiais paįvairinama dalykiniais tekstais bei specialiu žodynu; b. Profesinès vokiečių kalbos pratybos tampa dalykinès kalbos mokymu. Tokiu atveju pagrindine mokomąja medžiaga tampa specialybès vadovèlis vokiečių kalba su tam tikrais dalykiniais tekstais ir terminologija, kartais papildomas bendrinès kalbos užduotimis, nukopijuotomis iš bendrinès kalbos vadovèlių; c. Tik retais atvejais pasitelkiami vadovèliai, tiesiogiai pritaikyti besimokančiųjų grupei su jai pritaikytomis profesinemis bei kalbinemis situacijomis (Funk 1992: 5). Bet besimokantieji beveik ar apskritai neturi specialiųjų dalykinių žinių ir užsienio, ir gimtąja kalba. Todèl Elisabeth Lattaro daro tokią išvadą: per profesinę vokiečių kalbos pamoką geriausiu atveju galima išmokyti besimokantiji susidoroti su dalykinès kalbos reikalavimais, supažindinti ji su mokymo technika ir metodais, kuriais remiantis jis išmoks savarankiškai suprasti, išmokti ir perimti naują žodyną, nes dalykinė kalba ar, kitaip tariant, specialusis žodynas neturint specialių žinių yra beveik neįveikiamas (Lattaro 1991: 9).

Turèdami tai omenyje, plačiau panagrinèkime darbą su specialiaja terminija (žodynu), tekstais ir gramatika mokant profesinès kalbos, dar neturint profesinès patirties.

Darbas su žodynu visuose specialiosios literatūros vadovèliuose, mokymo planuose ir pratybų sąsiuviniuose turi daug reikšmès. Ir pagrịstai. Dalykinis žodynas plètojasi kur kas dinamiškiau nei kokia kita kalbinès sistemos dalis. „Kuo dažniau mes savo kasdieniniame gyvenime susiduriame su mokslo ir technikos pasekmèmis, tuo daugiau naudojame dalykinès kalbos terminų" (Funk 1990: 22). Tačiau, jei mokydamiesi dalykinès kalbos remsimès tik akumuliacijos, žodžių kaupimo principu, - toli nenueisime. Tuo labiau kad labai sunku numa- tyti, kokie žodžiai būsimai profesijai bus reikalingi. Tokiu atveju, mokantis profesinès kalbos ir dirbant su žodynu, būtina laikytis tam tikrų principų, pvz., būtina orientuotis ị žodžius, $k u$ rie yra universalūs ir vartotini ne tik tam tikroje dalykineje kalboje ar kalbant tik tam tikra tema, bet svarbūs kiekviename kontekste. Kaip pavyzdi čia galima pateikti:

a) veiksmažodžius, išreiškiančius santykị su skaičiais, dydžiais ir kiekiais:

... sich belaufen auf... ...teilen... ... sich ergeben...

...addieren... ...subtrahieren... ...multiplizieren... ir kt.

b) veiksmažodžius, išreiškiančius didejjimą arba mažejjimą:

+...vermehrt sich um... -...vermindert sich um...

...nimmt $z u(u m) \ldots$...nimmt $a b(u m) \ldots$

...steigt... ...fällt...

Taip pat reikètų išskirti: žodžius, kurie siejasi tik su tam tikra specifine sritimi; žodžius, kuriuos besimokantieji supranta ir véliau atpažista; žodžius, kuriuos jie aktyviai vartoja. Todèl per profesinę vokiečių kalbos pamoką, stengiantis išmokti vartoti visų šių rūšių žodžius, būtina daug dèmesio skirti žodžių darybai. Žodžių darybos taisyklès labai svarbios profesinès kalbos terminams sudaryti, jiems įsiminti, o jų mokejjimas lengvina dalykinių tekstų suvokimą.

Žodžiu išmokimą lengvina ir jų skirstymas pagal prasmę bei forma. Taigi svarbiausia yra supažindinti besimokančiuosius su mokymo tikslais, technika ir metodais, kurie padeda jiems savarankiškai suprasti, išmokti ir perimti žodžius, nustatyti jų reikšmes iš konteksto, pasinaudoti žodžių darybos taisyklemis ir pritaikyti juos pagal paskirtị.

Mokant dirbti su profesija susietais tekstais užsienio kalba, galioja tie patys tikslai, metodai bei darbo formos, kaip ir dirbant su visais kitais bendrinès kalbos tekstais. Bet ir čia reikètų išskirti keletą darbo su dalykiniais tekstais ypatumų.

Pirmiausia - tekstų parinkimas. Kokie tekstai tinka su profesija susietai užsienio kalbai 
dèstyti ir kokie netinka? Būtina atkreipti dèmesi $\mathfrak{i}$ tai, kad, norint geriau suprasti dalykinius tekstus, pirmiausia reikia gerai susipažinti su visomis tekstų rūšimis, pasitaikančiomis bendrinejje vokiečiu kalboje, daugiausia dèmesio skiriant informaciniams tekstams. Taigi parenkant konkrečius tekstus D. Möhnas ir L. Pelka (Möhn 1984: 7) rekomenduoja atsižvelgti i tokius principus:

- aiškus tekstų ryšys su besimokančio jaunimo gyvenamąja bei studijų aplinka;

- tekstuc parinkimo tikslas negali būti vien dalykinis mokymas. Darbas su tekstu turi mokyti naudotis ivairiomis darbo formomis;

- teksto parinkimas privalo reprezentuoti tam tikros profesijos dažniausiai pasitaikančias teksto rūšis bei perduodamą dalykinę informaciją;

- parinkti tekstai turètų skatinti profesinius motyvus, o ne atvirkščiai.

Tokie tekstai galètų būti ịvairūs darbo procesų aprašymai; tekstai iš tam tikros specialybès vadovèlių vokiečių kalba; naudojimosi taisyklès; darbo skelbimai; korespondencija; žinynai; produktų aprašymai, katalogai bei kainynai; ivvairūs prospektai; statistiniai duomenys ir lentelès; firmų bei įmonių aprašymai; reklaminiai tekstai.

Su šiais tekstais galima atlikti daugybę ịvairiausių užduočių, pvz., sudaryti tam tikram tekstui aktualaus žodyno sąrašą; aprašant darbo procesus, suskirstyti ir surūšiuoti darbo eigos pakopas; perskaitytą informaciją perduoti žodžiu; skaičius susieti su informacija, perduodant ją paprastais savais žodžiais; surinkti statistinę informaciją, ją suskirstyti ir palyginti; darbo skelbimuose pasižymèti ir aprašyti darbo sąlygas bei remiantis tekstu suformuluoti klausimus; nagrinèti laiškų rašymo pavyzdžius, suvokiant ir pritaikant jiems būdingus posakius. Nagrinejant produktų katalogus, aprašyti ir palyginti produktus, nurodyti jų trūkumus ir privalumus; parašyti perskaitytos informacijos santrauką, sudaryti teksto klausimus, atsakyti ị juos ir kt.

Kai kurie nuolat pasitaikantys veiksniai dalykiniuose tekstuose netgi palengvina jų suvoki- mą, lyginant juos su tekstais, nagrinèjamais per bendrinès kalbos pratybas. Tai vizualios priemonès, nuolat besikartojančios kalbinès priemonès bei gramatinès struktūros.

Dinamiškas dalykinių tekstų žodyno plètimasis mokantis profesinès kalbos yra vienas iš pagrindinių sunkumų, o gramatinių struktūrų, vartotinų dalykinejje kalboje, kiekis tikrai nedidelis. Lengvinantis veiksnys yra tai, kad visos šios gramatinès struktūros visai nesudètingos ir išmoktos jau mokykloje. $\mathrm{O}$ jei taip ir nèra, jas nesunku išmokti ir perimti. Pagrindinius profesinès kalbos mokymui naudojamus tekstus D. Möhnas ir L. Pelka (Möhn 1984: 12) priskiria dviem grupèms: a) jie informuoja arba b) instruktuoja, taigi aprašo darbo ir gamybos eigą arba būdą, kaip tai atliekama. Todèl tekstuose vartojama tiksli ir lakoniška kalba, nuolat griebiamasi tų pačių kalbinių priemonių, pvz., Passiv (neveikiamosios rūšies) formos; modaliniai veiksmažodžiai müssen, sollen, sein $+z u+$ Infinitiv, Imperativ (liepiamosios nuosakos) formos; priešdèliai, priesagos, sudurtiniai žodžiai, sudaiktavardinti veiksmažodžiai ir kt.

Gramatiškai nagrinejjant tekstus, būtina aptarti šias gramatines struktūras ir bandyti jas išmokti. Bet ir čia pagrindinis tikslas turi būti gramatinių struktūrų atpažinimas ir šifravimas. Nebūtina kiekvienu atveju jas atgaminti. Svarbiausia išmokyti besimokančiuosius gramatiškai supaprastinti sudètingas gramatines struktūras. Pvz., Passiv (neveikiamosios rūšies) konstrukcijas paversti Aktiv (veikiamąja rūšimi) ir, atvirkščiai, pažyminiui išreikšti šalutiniais sakiniais ir kt. Dalykinius tekstus besimokantieji pirmiausia turi suprasti, o ne atgaminti. Jei šiuos tekstus besimokantieji turi atpasakoti raštu ar žodžiu, privalo vartoti paprastesnes gramatines struktūras. Nuo sunkesnio - prie lengvesnio - toks turètu būti gramatikos mokymasis nagrinejjant profesinius su kalbos mokymu susietus tekstus.

\section{Išvados}

Apibendrinant reikia pabrèžti, kad negalima profesinès kalbinès kompetencijos sutapatinti su 
dalykine kompetencija ir kad profesinès vokiečių kalbos pamoka pirmiausia yra užsienio kalbos pamoka su visomis jai būdingomis strategijomis, metodais ir tikslais, padedančiais išmokti, suvokti ir įsiminti pateiktą informaciją.

\section{Literatūra}

Funk, H. 1992. "Berufsbezogener Deutschunterricht". in Grundlagen - Lernziele - Aufgaben, in Fremdsprache Deutsch. Sondernummer. München: 5.
Funk, H. 1990. "Arbeit mit dem Wörterbuch im Deutschunterricht", Fremdsprache Deutsch 3: 22 .

Lattaro, E. 1991. "Grundprobleme de berufsbezogenen Deutschunterrichts", Fremdsprache Deutsch 3: 9.

Möhn, D. Pelka, R. 1984. "Fachsprachen. Eine Einführung”, Tübingen: 7-12.

\section{BERUFSBEZOGENER DEUTSCHUNTERRICHT}

\section{Irena Miculevičienè}

In diesem Artikel geht es um Deutschunterricht für eine bestimmte Zielgruppe. Berufsbezogener Fremdsprachenunterricht ist in der Regel Unterricht mit Jugendlichen, die in der beruflichen Bildung kaum fachliche Kenntnisse haben. Deshalb besteht die Vorbereitung der Lernenden auf die lexikalischen Anforderungen eines Berufes darin, ihnen Techniken zu vermitteln, mit deren Hilfe sie neuen Wortschatz selbständig verstehen, lernen und behalten können. Hier spricht man auch über die Textarbeit, die die text-didaktischen Mittel der stufenweisen Annäherung vom globalen zum detaillierten Verstehen nutzt. Besonderheiten fachsprachlicher Texte in Inhalt, Wortschatz und Grammatik werden darüber hinaus gezielt bewusst gemacht. Was die Grammatikarbeit betriff, so müssen grammatische Strukturen erkannt und entschlüsselt, aber nicht in jedem Fall produziert werden. Wenn sie wiedergegeben werden, so muss man sie in eigenen Worten und mit einfacheren grammatischen Strukturen wiedergeben.

Schlüsselworte: berufsbezogene Sprache, Fachsprache Fachwortschatz, Beronderheiten der Fachtexte, grammatische Strukturen, Umgangssprache.

Iteikta 2006-01-16; priimta 2006-02-22 